\title{
Delta and Notch-Like Epidermal Growth Factor-Related Receptor
}

National Cancer Institute

\section{Source}

National Cancer Institute. Delta and Notch-Like Epidermal Growth Factor-Related

Receptor. NCI Thesaurus. Code C115972.

Delta and Notch-like epidermal growth factor-related receptor (737 aa, $78 \mathrm{kDa}$ ) is encoded by the human DNER gene. This protein plays a role in the positive regulation of Notch signaling. 